Aim of the study: The present study was aimed at estimating the prevalence of oral complications in cancer patients receiving chemotherapy. Material and methods: The study was conducted on a group of 58 patients treated with chemotherapy (study group). The control group consisted of 30 healthy patients. Dental status and oral mucosa were examined using the criteria of the National Cancer Institute Toxicity Criteria Scale. The levels of stimulated and unstimulated saliva flow were analysed.

Results: In the group of patients treated with chemotherapy, $59 \%$ of patients had inflammatory changes of the soft tissues of the mouth, such as erythema, erosions, or ulcers, which were discovered during dental examination. Such changes occurred in only $10 \%$ of patients in the control group. Six of the patients treated with chemotherapy reported pain with intensity was so severe that it caused swallowing difficulties. Patients in the study group frequently complained about the presence of dry mouth, taste disturbances, nausea, and vomiting. These symptoms occurred in $70 \%$ of patients undergoing oncological treatment. In both stimulated and unstimulated saliva secretion, the rates were significantly lower in patients from the research group, when compared to the control group.

Key words: chemotherapy, oral mucositis, treatment complications, cytotoxicity.

Contemp Oncol (Pozn) 2015; 19 (1): 77-82 DOI: 10.5114/wo.2014.45291

\section{Analysis of the influence of parenteral cancer chemotherapy on the health condition of oral mucosa}

\author{
Mansur Rahnamaํ, Barbara Madej-Czerwonka², Izabela Jastrzębska- \\ -Jamrogiewicz ${ }^{1}$, Rafał Jamrogiewicz ${ }^{1}$
}

${ }^{1}$ The Chair and Department of Oral Surgery, Medical University of Lublin, Lublin, Poland ${ }^{2}$ Department of Breast Surgery, Regional Specialist Hospital, Lublin, Poland

\section{Introduction}

Systemic chemotherapy is used in the treatment of neoplastic lesions. Therapy using cytotoxic drugs causes damage to the rapidly dividing cancer cells. Alkylating agents cause DNA damage of tumour cells, antimetabolites interfere with the structure of DNA and RNA, anthracyclines interfere with enzymes involved in DNA replication, topoisomerase inhibitors interfere with the enzyme activity necessary to separate the strands of DNA before replication, and mitosis inhibitors prevent cell division. Chemotherapeutic agents are used in preoperative (neoadjuvant therapy) or postoperative treatment (adjuvant therapy), as a separate treatment of certain types of cancer (e.g. tumours of bone marrow) and in neoplasm changes that have spread in the organism.

It should be noted that, along with the many benefits of the therapeutic effect of cytostatics, chemotherapy causes a number of possible complications. The side effects of chemotherapy result from low-specificity of drugs. Chemotherapeutics operate systemically by destroying not only neoplastic tumour cells, but also the healthy cells of the patient's organism. Cells that are particularly at risk are the cells that divide quickly, such as hair follicles, epithelium of the gastrointestinal tract, and bone marrow. This results in higher risk of cancer therapy complications in these particular tissues. Furthermore, pharmacological therapy leads to modification of the bacterial flora in the oral cavity, and immune system deficiency [1]. This leads to increased secretion of pro-inflammatory factors and reduction of the effectiveness of the immune system. The number of neutrophils and lymphocytes, in particular CD 4 lymphocytes, is reduced [2].

In addition to systemic actions, cytostatics have a local effect on the stomatognathic system. Chemotherapy reduces the secretion of saliva, which functions not only as a barrier against mechanical factors and pathogenic microorganisms, but also takes part in the reception of taste stimuli [3]. Lack of the protective effect of salivary glands secretions favours mechanical trauma of the oral mucosa. It should also be noted that cytotoxic drugs have a toxic effect on the cells of the epithelium basal layer, causing dysfunction of epithelium cells and induction of apoptosis, which leads to thinning of the epithelium and failure of mucosa regeneration. Damaged epithelial tissue allows microorganisms to penetrate into the tissues and the bloodstream. The impaired immune response of the patient also favours infection. Moreover, the "Oncology Nursing Society Research Priorities" state that the pathological changes manifested in the oral cavity are among the most common side effects of cytotoxic activity [4]. 


\section{Aim of the study}

The study was aimed at investigating the prevalence of side effects of chemotherapy occurring in the oral cavity. The state of the mucous membranes of the mouth, the saliva flow, and the presence of subjective symptoms among cancer patients receiving chemotherapy were also estimated.

\section{Material and methods}

A clinical trial was conducted on a group of 58 patients receiving chemotherapy (mean age 63.87 years, 42 women and 16 men). Patients were treated in the Department of Internal Medicine, Endocrinology, and Diabetology within the Oncology Unit of the Provincial Specialist Hospital in Lublin. The control group consisted of 30 healthy patients (mean age 61.56 years, 18 women, 12 men), patients of Dental Clinical Center of Medical University in Lublin. Patients who were qualified for the study group were receiving Cyclophosphamide, Doxorubicin, Taxotere, Cisplatin, or Fluorouracil. Patients enrolled in the study had been receiving chemotherapy for at least four weeks, had no addictions, and did not use any removable dentures. All patients gave their consent for examination. Test procedures received the approval of the Local Ethics Committee in Lublin No. KE0254/41/2010.

Subjective evaluation of patients was divided into 3 parts. The first part of the study concerned general patient information: age, general illness, administered medication, and addictions. The second part of the questionnaire concerned the type of neoplasm and the type of administered chemotherapy (type of chemotherapeutic agent used, the dose, and the cycle). The third part concerned the subjective symptoms, such as the feeling of tension in mastication muscles, the feeling of burning in the oral cavity or paraesthesia, and objective symptoms such as dryness of oral mucosa, vomiting, or trismus, reported by the patient.

The physical examination concerned the status of the stomatognathic system. During the examination attention was paid to the condition of the teeth and oral mucosa (criteria of the division of epithelial lining inflammation of the National Cancer Institute Toxicity Criteria Scale were used, and in order to evaluate the pain level the visual analogue scale (VAS) was used). Fungal infection of the oral cavity was evaluated on the basis of typical clinical symptoms (coating of pseudomembranous white slough that can be easily wiped away revealing erythematous mucosa underneath), and in doubtful cases microbiological evaluation was made of a smear collected by scraping the pathological lesion with a spatula.

The level of stimulated and unstimulated saliva secretion was measured. Unstimulated saliva was collected from patients in a fasting state. The measurement was carried out in the morning hours (between 6 and 8 a.m.). Patients deposited saliva into test tubes. Both deposition time and volume of deposited saliva were measured. After 15 minutes from the end of unstimulated saliva deposition, patients were asked to chew paraffin for 5 minutes and measurement of stimulated saliva was carried out in a similar manner. The collected data made it possible to determine the rate of saliva secretion $(\mathrm{ml} / \mathrm{min})$.

Results were statistically analysed with use of QuickCals software. The arithmetic mean $(M)$ and standard deviation (SD) were calculated. The significance of differences between groups was based on unpaired $T$-test for medians. The significance of differences was marked with letters - in the tables in the column " $p$ " (means are significantly different if they are not marked with the same letter of the alphabet). The risk of error of inference of the study was $5 \%$, which means that the results were significant if $p$ was equal to or less than 0.05 .

\section{Results}

A comparison of the severity and frequency of pathological changes occurrence in the oral cavity of patients in the control and the study group is presented in Tables 1 and 2. In $90 \%$ of patients from the control group no mucosal lesions in the oral cavity were detected. Only erythema and mild

Table 1. Severity of inflammation of the mucous membrane according to the National Cancer Institute Toxicity Scale

\begin{tabular}{|c|c|c|c|c|c|c|}
\hline $\begin{array}{l}\text { Grading of oral } \\
\text { mucositis by NCITC } \\
\text { Scale }\end{array}$ & $\begin{array}{l}\text { Number of } \\
\text { patients from } \\
\text { the study group } \\
\text { reporting the } \\
\text { presence of } \\
\text { a particular } \\
\text { lesion }\end{array}$ & $\begin{array}{l}\text { Total } \\
\text { number of } \\
\text { patients } \\
\text { from study } \\
\text { group }\end{array}$ & $\begin{array}{l}\text { Percentage } \\
\text { occurrence of } \\
\text { a particular lesion } \\
\text { among patients } \\
\text { from study group }\end{array}$ & $\begin{array}{l}\text { Number of } \\
\text { patients from } \\
\text { the control group } \\
\text { reporting the } \\
\text { presence of } \\
\text { a particular lesion }\end{array}$ & $\begin{array}{l}\text { Total } \\
\text { number of } \\
\text { patients } \\
\text { from } \\
\text { control } \\
\text { group }\end{array}$ & $\begin{array}{c}\text { Percentage } \\
\text { occurrence of } \\
\text { a particular lesion } \\
\text { among patients } \\
\text { from control } \\
\text { group }\end{array}$ \\
\hline lack of inflammation & 24 & 58 & $41.379 \%$ & 27 & 30 & $90.000 \%$ \\
\hline $\begin{array}{l}\text { erythema, } \\
\text { painless ulcers, } \\
\text { mild soreness }\end{array}$ & 18 & 58 & $31.034 \%$ & 3 & 30 & $10.000 \%$ \\
\hline $\begin{array}{l}\text { painful erythema, } \\
\text { oedema, ulcers, } \\
\text { patient can eat }\end{array}$ & 16 & 58 & $27.586 \%$ & 0 & 30 & $0.000 \%$ \\
\hline $\begin{array}{l}\text { painful } \\
\text { erythema, oedema, } \\
\text { ulcers, patient unable } \\
\text { to eat }\end{array}$ & 1 & 58 & $1.724 \%$ & 0 & 30 & $0.000 \%$ \\
\hline $\begin{array}{l}\text { parenteral or enteral } \\
\text { support }\end{array}$ & 0 & 58 & $0.000 \%$ & 0 & 30 & $0.000 \%$ \\
\hline
\end{tabular}


Table 2. The incidence of pathological lesions of the mucous membranes

\begin{tabular}{|lcccccc}
$\begin{array}{l}\text { Pathological lesions } \\
\text { of oral mucosa }\end{array}$ & $\begin{array}{c}\text { Number of } \\
\text { patients from } \\
\text { a study group } \\
\text { with lesion }\end{array}$ & $\begin{array}{c}\text { Total number of } \\
\text { patients from }\end{array}$ & $\begin{array}{c}\text { Percentage occurrence } \\
\text { research group } \\
\text { among patients from } \\
\text { study group }\end{array}$ & $\begin{array}{c}\text { Number of } \\
\text { patients from } \\
\text { a control group } \\
\text { with lesion }\end{array}$ & $\begin{array}{c}\text { Total number } \\
\text { of patients } \\
\text { from control } \\
\text { group }\end{array}$ & $\begin{array}{c}\text { Percentage } \\
\text { occurrence of } \\
\text { a particular lesion } \\
\text { among patients } \\
\text { from control group }\end{array}$ \\
\hline $\begin{array}{l}\text { fungal lesions } \\
\text { hyperemia, } \\
\text { erythema }\end{array}$ & 29 & 58 & $50.000 \%$ & 1 & 30 & $3.333 \%$ \\
\hline ecchymosis & 30 & 58 & $51.724 \%$ & 3 & 30 & $10.000 \%$ \\
\hline erosion/ulceration & 24 & 58 & $41.379 \%$ & 3 & 30 & $10.000 \%$ \\
\hline
\end{tabular}

soreness were discovered in healthy patients. In the group of patients treated with chemotherapy, nearly $59 \%$ of patients had inflammatory changes of the soft tissues. Pathological lesions among healthy patients were less severe and were limited to painless redness or erosions, while inflammation in the study groups had a significantly higher intensity than in the healthy group. Lesions causing pain occurred in over $27 \%$ of patients. One of the patients treated with chemotherapy reported pain so intensive that it made it impossible to intake food. In addition, examination of the study group revealed fungal infection in $50 \%$ of patients, compared with one fungal infection in the control group (Fig. 1).

Table 3 presents the most frequently reported subjective symptoms from the stomatognathic system. Analysis of the results shows that the symptoms were reported more frequently by the patients in the study group. Only in the case of gingival bleeding was the situation was opposite - this symptom was reported by $23.33 \%$ of the patients in the control group, and $18.966 \%$ of the patients treated with chemotherapy. Patients in the study group frequently complained about the presence of dryness of mouth, taste disturbances, nausea, and vomiting. These symptoms occurred in more than $70 \%$ of patients (Fig. 2).

Table 4 presents the results of measurement of the rate of saliva flow. Stimulated and unstimulated saliva flow were both significantly lower in patients from the research group, when compared with the control group.

\section{Discussion}

Chemotherapeutic agents demonstrate toxicity to rapidly dividing cells. Tissues with rapid cell turnover are not only neoplasms, but also healthy tissues of the organism. The oral cavity is lined with rapidly dividing keratinising or non-keratinising stratified squamous epithelium (cell turnover within 5-8 days). Non-keratinising epithelium is located, inter alia, on cheeks, lips, soft palate, the floor of the mouth, and the ventral part of the tongue. Because of the nonspecific cytotoxic activity of chemotherapy, oral epithelial tissue is exposed to the toxic effects of chemotherapy. Cytotoxic drugs damage the oral mucosa by two mechanisms [5]: chemotherapy causes damage to the DNA of progenitor cells belonging to the basal layer of the epithelium, and it leads to induction of programmed cell death - apoptosis. Both mechanisms result in thinning of the epithelium and disorders of regeneration process. What is more, it has been stated that in submucosal tissues of patients receiving anti-neoplastic treatment, the levels of pro-inflammatory cytokines, such as tumour necrosis factor- $\alpha$, interleukin-1, and interleukin-6, are elevated. This fosters the development of inflammation and the formation of erosions and ulcerations. The results of the present study demonstrate that in more than $58 \%$ of patients treated with chemotherapeutic agents, epithelial lesions - erosions and ulcerations - are detected. UIcerative lesions did not occur among the patients in the control group. Among patients in the control group, only erythema or redness were detected. Elting et al., in their work, reported the outcome of a study involving 599 patients. During the 1236 cycles of chemotherapy, in 37\% of patients inflammation of the oral mucosa was stated [6].

Mazzeo et al. found that in the secretion of the salivary glands, cytostatic metabolites are present, which may further exacerbate inflammation of the mucous membranes of the oral cavity [7]. Analysis of questionnaires concerning subjective symptoms appearing in the stomatognathic system has shown that patients undergoing anti-neoplastic treatment experience significant discomfort associated with administered therapy. Patients from the study group complained more frequently on xerostomia (82.76\%), taste disorders (72.41\%), nausea, and vomiting $(82.76 \%)$ than did patients from the control group. The study by Dik-

[\%]

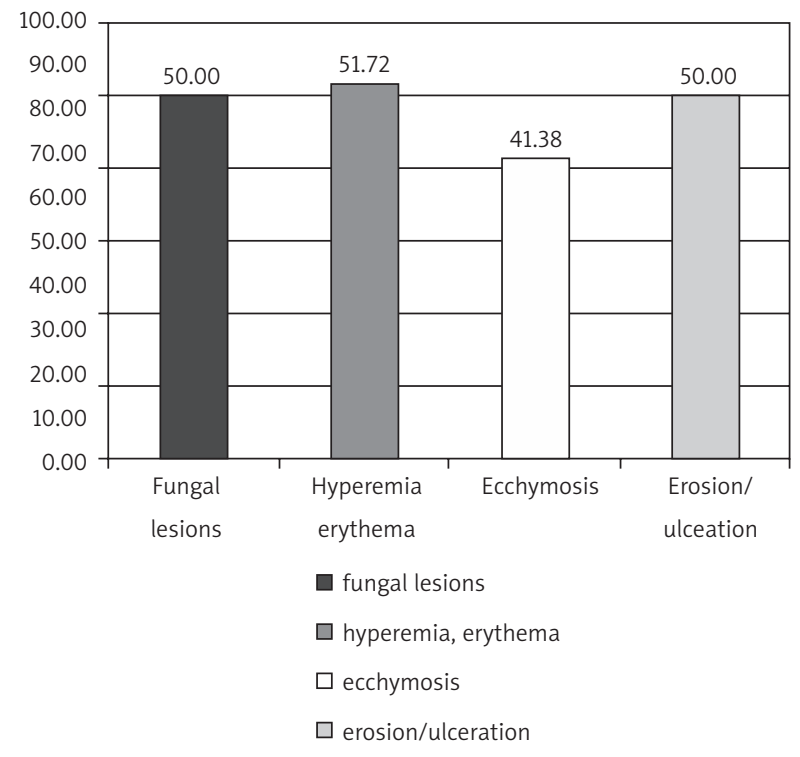

Fig. 1. The incidence of pathological lesions of the mucous membranes in patients treated with chemotherapy 
Table 3. The prevalence of subjective symptoms among examined patients

\begin{tabular}{|c|c|c|c|c|c|c|}
\hline $\begin{array}{l}\text { Subjective } \\
\text { symptoms }\end{array}$ & $\begin{array}{l}\text { Number of patients } \\
\text { from the study } \\
\text { group reporting } \\
\text { the presence } \\
\text { of a particular } \\
\text { symptom }\end{array}$ & $\begin{array}{l}\text { Total } \\
\text { number } \\
\text { of patients } \\
\text { from study } \\
\text { group }\end{array}$ & $\begin{array}{c}\text { Percentage } \\
\text { occurrence of } \\
\text { a particular symptom } \\
\text { among patients from } \\
\text { study group }\end{array}$ & $\begin{array}{l}\text { Number of patients } \\
\text { from the control } \\
\text { group reporting the } \\
\text { presence of a particular } \\
\text { symptom }\end{array}$ & $\begin{array}{l}\text { Total } \\
\text { number } \\
\text { of patients } \\
\text { from control } \\
\text { group }\end{array}$ & $\begin{array}{c}\text { Percentage } \\
\text { occurrence of } \\
\text { a particular symptom } \\
\text { among patients from } \\
\text { control group }\end{array}$ \\
\hline $\begin{array}{l}\text { feeling } \\
\text { of mouth } \\
\text { soreness }\end{array}$ & 14 & 58 & $24.138 \%$ & 0 & 30 & $0.000 \%$ \\
\hline $\begin{array}{l}\text { feeling of } \\
\text { burning in oral } \\
\text { cavity }\end{array}$ & 18 & 58 & $31.034 \%$ & 0 & 30 & $0.000 \%$ \\
\hline $\begin{array}{l}\text { dryness of oral } \\
\text { mucosa }\end{array}$ & 48 & 58 & $82.759 \%$ & 5 & 30 & $16.667 \%$ \\
\hline $\begin{array}{l}\text { feeling of "pins } \\
\text { and needles" } \\
\text { (paresthesia) }\end{array}$ & 13 & 58 & $22.414 \%$ & 0 & 30 & $0.000 \%$ \\
\hline $\begin{array}{l}\text { taste } \\
\text { disturbances }\end{array}$ & 42 & 58 & $72.414 \%$ & 0 & 30 & $0.000 \%$ \\
\hline $\begin{array}{l}\text { bleeding gums } \\
\text { (gingivitis) }\end{array}$ & 11 & 58 & $18.966 \%$ & 7 & 30 & $23.333 \%$ \\
\hline $\begin{array}{l}\text { difficulties in } \\
\text { food intake }\end{array}$ & 24 & 58 & $41.379 \%$ & 0 & 30 & $0.000 \%$ \\
\hline trismus & 6 & 58 & $10.345 \%$ & 0 & 30 & $0.000 \%$ \\
\hline $\begin{array}{l}\text { the feeling } \\
\text { of tension in } \\
\text { mastication } \\
\text { muscles }\end{array}$ & 8 & 58 & $13.793 \%$ & 0 & 30 & $0.000 \%$ \\
\hline $\begin{array}{l}\text { feeling of } \\
\text { numbness } \\
\text { and tingling of } \\
\text { lower lip }\end{array}$ & 13 & 58 & $22.414 \%$ & 2 & 30 & $6.667 \%$ \\
\hline $\begin{array}{l}\text { feeling of } \\
\text { inappropriate/ } \\
\text { unpleasant } \\
\text { sensation } \\
\text { (dysesthesia) }\end{array}$ & 2 & 58 & $3.448 \%$ & 0 & 30 & $0.000 \%$ \\
\hline $\begin{array}{l}\text { nausea and } \\
\text { vomiting }\end{array}$ & 48 & 58 & $82.759 \%$ & 0 & 30 & $0.000 \%$ \\
\hline
\end{tabular}

ken reported that nausea occurred in $54 \%$ of patients [8]. Brown et al., in their work, reported 223 cases of patients undergoing systemic antitumor therapy. In 51\% of these patients pain, burning, and dryness described as "soreness of the mouth" (sore mouth syndrome) occurred [9]. Studies conducted by Cheng on 88 patients undergoing cancer therapy showed that $72 \%$ of patients had a feeling of mouth dryness, $63 \%$ had taste disorders, and $40 \%$ reported difficulties in swallowing [10]. The results obtained in the present study allow us to state unequivocally that chemotherapy has a significant impact on the quality of patients' life. It is worth noting that the severity of symptoms may even make it impossible to intake food. One patient from the study group had such severe oral mucositis that pain made it impossible to administrate solid food. Slightly higher incidence of bleeding gums stated in the control group, compared to the study group, may be associated with more frequent teeth brushing by healthy patients. Usually patients observe gingival bleeding directly after teeth brushing. Patients during chemotherapy are usually weak and occasionally are unable to perform oral hygiene procedures, so they do not observe gingival bleeding. The ecchymosis found in three patients from control group was probably the result of mechanical injury during the process of biting - the ecchymoses were located in the mucosa of the cheek on the level of the occlusion line. The high rate of ecchymosis in oncological patients may be a result of the negative influence of cytotoxic drugs on bone marrow cells. Ecchymosis can be a sign of a low platelet count during therapy. It should be noted that submucosal extravasation of blood in patients from the study group was located in different areas of the oral cavity (soft palate, floor of the mouth, lower lip, and mucosa of the cheek). The erythema found in $10 \%$ of patients from the control group can be associated with chronic periodontitis. The incidence of erythema in th study group is significantly higher than in healthy patients (51.724\%), which is the result of the failure of the immune system 


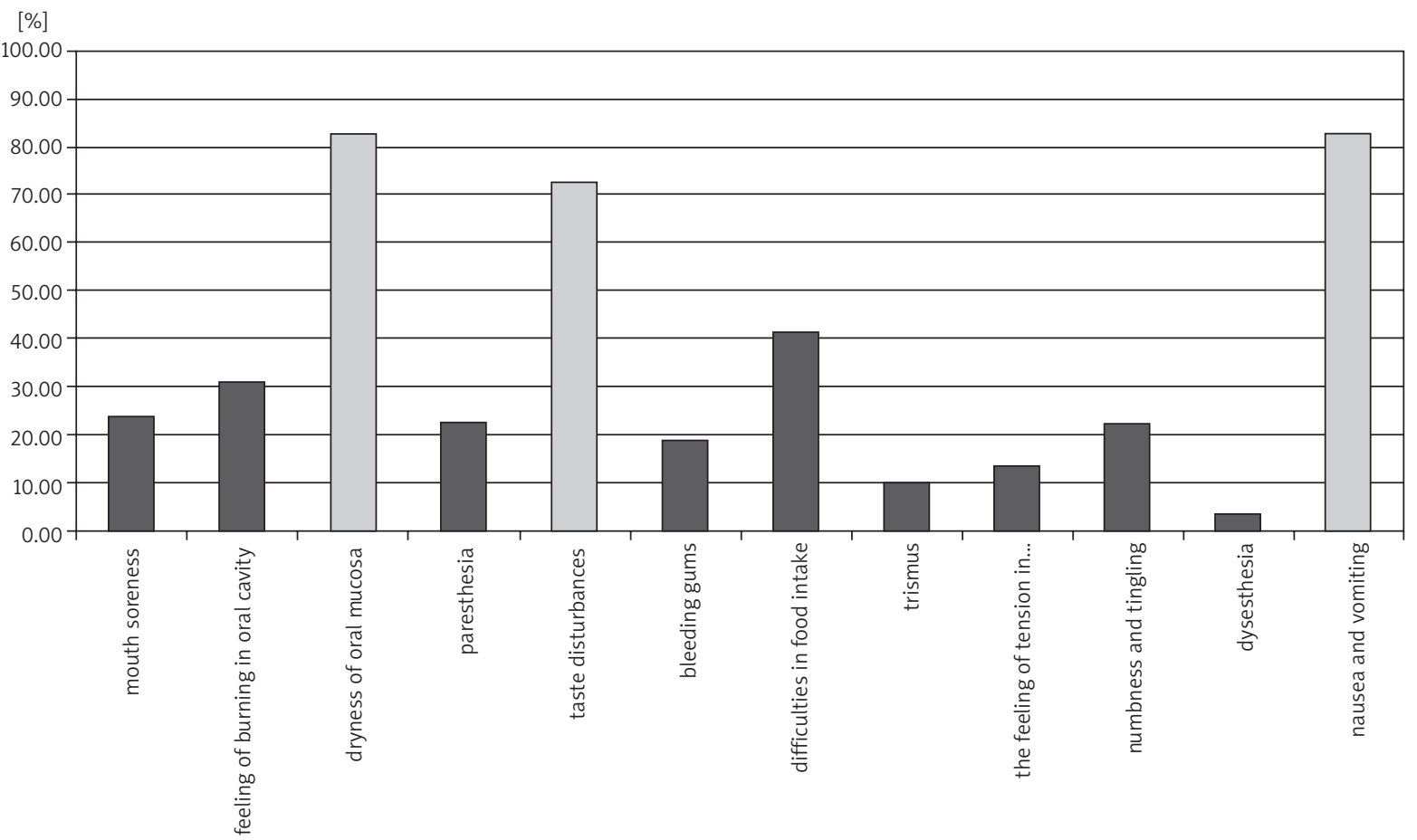

*Red colour indicates the most common symptoms reported by patients

Fig. 2. The prevalence of subjective symptoms among patients treated with chemotherapy

and increased inflammation process in the periodontal sockets.

An important and frequently occurring complication of chemotherapy is oral candidiasis. Fungal infections are promoted by reduction of salivation, neutropaenia, lymphocyte disorders, and changes in the bacterial flora of the oral cavity [11]. Silverman et al. described the effect of co-aggregation between certain strains of bacteria, in particular Streptococci and the fungus Candida albicans [12]. Other synergistic interactions can be found between oral fungi and Staphylococcus aureus [13]. The results obtained in the present study showed that fungal changes occurred at least once during therapy in 29 patients treated with cytostatics (50\% of patients). Such changes occurred only in one patient in the control group. This allows us to state the thesis that there is a relationship between the effects of chemotherapy and the incidence of fungal infections of the mouth.

The results of the rate of salivation measurements clearly indicate that systemic chemotherapy leads to reduction of saliva secretion by the salivary glands. Stimulated (stimulated whole saliva - SWS) and unstimulated (non-stimulated whole saliva - nSWS) saliva release rates were lower in the study group compared to the control group. These results are consistent with the outcomes of the study by Harrison et al., who studied the rate of SWS secretion in patients treated with cyclophosphamide, methotrexate, and fluorouracil [14]. The results obtained by Harrison et al. showed that SWS secretion in patients undergoing chemotherapy was significantly lower $(0.96 \mathrm{ml} / \mathrm{min})$ than in healthy patients $(2.33 \mathrm{ml} / \mathrm{min})$ and lower than in patients with cancer who were not yet subjected to systemic therapy $(1.81 \mathrm{ml} / \mathrm{min})$. Jensen et al. showed that the reduced secretion of saliva can persist for up to a year after treatment with cytotoxics. About 12 months after the completion of chemotherapy, the rate of secretion and the amount of saliva flow return to normal [15]. Saliva insufficiency greatly promotes the development of oral lesions. Reduced salivary gland secretion leads to increased epithelial mechanical damage due to a lack of moisturisation of mucosal membranes. Moreover, the defence activity of saliva is reduced due to lack of immunoglobulins, lysozyme, lactoferrin, and other antibacterial substances contained in saliva. Research conducted by McCarthy et al., performed on 63 patients treated with fluorouracil, showed that there is a relationship between chemotherapy-induced reduction in saliva secretion and neutropaenia, and the occurrence of inflammation of the oral mucosa [16]. In the present study, dryness of the mouth was stated by $82.759 \%$ of examined patients during chemotherapy. The decrease in salivary flow is a factor that has a significant influence on the exacerbation of all inflammation processes in the oral cavity and higher incidence of mechanical injuries of mucosa due to lack of lubrication. Dryness of the mouth in the control group (16.667\%) was discovered in menopausal women. The menopause is accompanied by the occurrence of oral symptoms. One of the most common complaints reported by menopausal women is the feeling of xerostomia and burning mouth. In most cases the feeling of dryness in only a subjective complaint and the examination of salivary flow and status of oral mucosa does not reveal abnormalities. In the present study women who complained of mouth dryness were free from ulcerations or severe oral inflammations $[17,18]$. It should also be noted that saliva is essential in the process of flavour recognition. Insufficient moisturisation of the oral mucous membranes alters the perception of taste stimuli. The taste disorders reported by $72.414 \%$ of the patients in the study 
group may result from a reduced level of stimulated saliva secretion. It should be noted that in some cases, taste disturbances lead to a reduction in the appetite of patients. Nausea, vomiting, and lack of appetite can result in malnutrition of the body. Deficiency of nutrients can significantly worsen the patient's condition, exacerbating the side effect symptoms of chemotherapy.

Oncological treatment with cytotoxic drugs leads to a number of side effects, which are localised in the stomatognathic system. These oral complications can greatly reduce the quality of patients' lives. What is more, oral inflammations can lead to extremely dangerous systemic infections in patients whose immune system is compromised by cytotoxic agents. Prevention or early detection of local oral pathologies is important in the treatment process of oncological patients. Local treatment of oral infections with antibiotic-antifungal agents, supporting the systemic treatment and improving the overall blood morphology in oncological patients, leads not only to improvement in the condition of the oral epithelium, but also the general health status of patients. Co-operation between the oncologist and other specialists during the process of anti-neoplastic treatment can improve the quality of patients' lives and ameliorate the results of therapy [19].

In conclusion:

1. Cytotoxic therapy is often associated with the occurrence of side effects in the oral cavity, due to the low specificity of the action of chemotherapeutic agents.

2. An important factor intensifying the occurrence of oral inflammations and infections is insufficient secretion of salivary glands.

3. The higher risk of the occurrence of pathological changes in the stomatognathic system of patients during chemotherapy, compared to the healthy population, should be taken into consideration during the planning of oncological treatment. Patients should be subjected to a stomatological examination before the start of therapy to minimise the risk of oral complications. It should also be mandatory for patients to undergo periodic stomatological check-ups during the period of chemotherapy so that any lesions or pathologies can be discovered and treated.

\section{The authors declare no conflict of interest.}

\section{References}

1. Galili D, Donitza A, Garfunkel A, Sela MN. Gram-negative enteric bacteria in the oral cavity of leukemia patients. Oral Surg Oral Med Oral Pathol 1992; 74: 459-62.

2. Solomayer EF, Feuerer M, Bai L, et al. Influence of adjuvant hormone therapy and chemotherapy on the immune system analysed in the bone marrow of patients with breast cancer. Clin Cancer Res 2003; 9: 174-80.

3. de Almeida Pdel V, Grégio AM, Machado MA, de Lima AA, Azevedo LR. Saliva composition and functions: a comprehensive review. J Contemp Dent Pract 2008; 9: 72-80.

4. Doorenbos AZ, Berger AM, Brohard-Holbert C, et al. 2008 ONS research priorities survey. Oncol Nurs Forum 2008; 35: 100-7.
5. Sonis ST. A biological approach to mucositis. J Support Oncol 2004; 2: $21-36$.

6. Iting LS, Cooksley C, Chambers M, Cantor SB, Manzullo E, Rubenstein EB. The burdens of cancer therapy. Clinical and economic outcomes of chemotherapy-induced mucositis. Cancer 2003; 98: 1531-9.

7. Mazzeo MA, Linares JA, López MM, et al. Analysis of saliva samples from oncological patients treated with 5-fluorouracil and leucovorin calcium by scanning electron microscopy with energy dispersive system. J Oral Pathol Med 2013; 42: 788-92. doi: 10.1111/ jop.12078

8. Dikken C, Sitzia J. Patients' experiences of chemotherapy: side-effects associated with 5-fluorouracil + folinic acid in the treatment of colorectal cancer. J Clin Nurs 1998; 7: 371-9.

9. Brown CG, McGuire DB, Peterson DE, Beck SL, Dudley WN, Mooney $\mathrm{KH}$. The experience of a sore mouth and associated symptoms in patients with cancer receiving outpatient chemotherapy. Cancer Nurs 2009; 32: 259-70.

10. Cheng KK. Oral mucositis, dysfunction, and distress in patients undergoing cancer therapy. J Clin Nurs 2007; 16: 2114-21.

11. Deslauriers N, Coulombe C, Carré B, Goulet JP. Topical application of a corticosteroid destabilizes the host parasite relationship in a experimental model of the oral carrier state of Candida albicans. FEMS Immunol Med Microbiol 1995; 11: 45-6.

12. Silverman RJ, Nobbs AH, Vickerman MM, Barbour ME, Jenkinson HF. Interaction of Candida albicans cell wall Als3 protein with Streptococcus gordonii SspB adhesin promotes development of mixed-species communities. Infect Immun 2010; 78: 4644-52.

13. Shirtliff ME, Peters BM, Jabra-Rizk MA. Cross-kingdom interactions: Candida albicans and bacteria. FEMS Microbiol Lett 2009; 299: 1-8.

14. Harrison T, Bigler L, Tucci M, Pratt L, Malamud F, Thigpen JT, Streckfus $C$, Younger $H$. Salivary slgA concentrations and stimulated whole saliva flow rates among women undergoing chemotherapy for breast cancer: an exploratory study. Spec Care Dentist 1998; 18: $109-12$

15. Jensen SB, Mouridsen HT, Reibel J, Brünner N, Nauntofte B. Adjuvant chemotherapy in breast cancer patients induces temporary salivary gland hypofunction. Oral Oncol 2008; 44: 162-73.

16. McCarthy GM, Awde JD, Ghandi H, Vincent M, Kocha WI. Risk factors associated with mucositis in cancer patients receiving 5 -fluorouracil. Oral Oncol 1998; 34: 484-90.

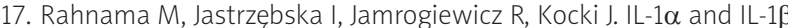
levels in blood serum and saliva of menopausal women. Endocr Res 2013; 38: 69-76.

18. Agha-Hosseini F, Mirzaii-Dizgah I, Moghaddam PP, Akrad ZT. Stimulated whole salivary flow rate and composition in menopausal women with oral dryness feeling. Oral Dis 2007; 13: 320-3.

19. Pels E. Oral mucositis in children suffering from acute lymphoblastic leukaemia. Contemp Oncol (Pozn) 2012; 16: 12-5.

\section{Address for correspondence}

\section{Rafał Jamrogiewicz}

The Chair and Department of Oral Surgery

Medical University of Lublin

Karmelicka 7

20-081 Lublin, Poland

e-mail: rafal.jamrogiewicz@gmail.com

Submitted: 30.12 .2013

Accepted: 11.04 .2014 